\title{
Law of Individuality and Locard's Principle from Islamic Perspective
}

\author{
Ahmad Syukran Baharuddin ${ }^{1}$ \\ Mohammad Amir Wan Harun 1 \\ Aminuddin Ruskam ${ }^{1}$ \\ Abdul Abdul Rahim Yacob² \\ ${ }^{1}$ Faculty of Islamic Civilisation, Universiti Teknologi Malaysia, Skudai, Johor, Malaysia \\ ${ }^{2}$ Department of Chemistry, Faculty of Science, Universiti Teknologi Malaysia, Skudai Johor, Malaysia
}

\section{Doi:10.5901/mjss.2016.v7n1p239}

\section{Abstract}

The term figh forensics is a combination of 'the theory and philosophy of Islamic law' and 'the scientific approach in investigation' which can explain the crucial need to combine and integrate these two fields. This article attempts to explore the concept of figh forensics and its application in life especially in the field of al-'Uqubat (punishment) within the discussion of basic forensic principles. Focus is given to the two most important principles in practical forensics namely; Locard's Principle and Law of Individuality. Deductive, inductive and historical methods of textual analysis are used in this work. The study found that the combination of these two fields is a must and it is in line with maqasid al-Shari'ah in al-'uqubat. However, the integration must be in compliance with the Islamic guideline, ethics, maxims and approaches.

Keywords: Locard's Principle; Law of Individuality; Islamic Philosophy of Forensic Science; Forensics; Fiqh Forensics

\section{Introduction}

From the Islamic perspective scientific findings seldom bring disappointment for science and religion are not intended to be separated. Prophet Muhammad (p.b.u.h.) once allowed his companions to pollinate date trees using their knowledge and skills for improved yield purpose showing that Islam does not have any restriction on the application of science in worldly matters such as agriculture (al-Nawawi, 1972). Likewise the principle is applicable in the field of technology. What should be taken into consideration is the way the technology is used, its ethics and approaches, and the maxims employed. The use of DNA for example shows how the human race is blessed with the al-'Aql to help regulate the running of a society by solving criminal cases wisely. Through the application of ethics and etiquette, the optimization of the use of technology within the control of al-'Aql as science could be instrumental in helping to ensure that the maqasid al-Shari'ah is being fulfilled. Noting that the field of forensics was proven to help in solving crimes and assist other field, but academic discussion of its fundamentals is still a bizarre in Islam (Ahmad Syukran Baharuddin, et al., 2015). Previous scholars made extensive analysis on the field of al-Qarinah and al-Bayyinah and coincidently left the fundamentals of forensics part unassociated with maqasid al-Shari'ah resulting a huge gap between forensics and maqasid al-Shari'ah. With that, this paper aims to elaborate on the concept of figh forensics within the limitation of the Law of Individuality and Locard's Principle towards the realization of maqasid al-Shari'ah.

\section{Methods}

Research findings are presented from deduction analysis on data gained from scholarly documents related to the concept of figh forensics. These consist of relevant data from primary sources under the topic of al-Qarinah and al-Bayyinah in Islamic Law. Thus, meta-analysis is being done based on induction method to show on the integration between related phrases with the two important principles in practical forensics namely the Locard's Principle and Law of Individuality. The primary sources come from related manuscripts discussing the topics of al-Qarinah, al-Bayyinah and al-Uqubat. Secondary sources consist of journals, books, articles, and other related materials. All of these materials are discussed thoroughly in this paper using historical, deductive, and inductive analysis. 


\section{Results and Discussion}

\subsection{The Concept of Fiqh Forensics and A Brief History of Forensics in Islam}

This article tries to introduce a rejuvenated concept of integration between the application of science and Islamic criminal law. The term 'Figh Forensics' originally suggested in this article aims to demonstrate the importance of integration between science and Islamic law. No scholars have yet to define and properly discuss the concept of figh forensics in any Islamic classical references (Ahmad Syukran Baharuddin, et al., 2015). It has however been described as a separate chapter of al-Qarinah, al-Bayyinah and al-Qiyafah in Islamic law. Forensic pathology for example, has been highlighted in unspecific way under the chapter of ahkām al-Jarahah (rule of wound), mafqud (al-Zayla'i, 1992) and al-Janaiz (alSharbini, 1994). The Arabic word 'figh' is literally described as deep understanding, full apprehension and obtaining sufficient knowledge of the religion (Ibn Manzur, 1994). Al-Zarkashī (1994) in al-Bahr al-Muhit defined figh as "al-'Ilm bi Ahkam al-Shar'iyyah al-'Amaliyyah min Adillatiha al-Tafsiliyyah" (the practical knowledge of revealed rulings derived from detailed evidences or scripts) while Khatib al-Sharbini (1994) describes the relevancy of figh to be considered under the knowledge to concern on the actions of mukallaf whether it is permissible, prohibited, recommended and others. Fiqh is termed to cover a vast scope in everything related to the practicality of human life such in Muamalat, Munakahat, Mawarith, Ibadah, and even 'At'imah (foods) (al-Zuhayli, n.d.).

The word 'forensic' is derived from Latin word 'forensis' or 'forum' which is originally to signify the act of debating in legal circumstances. In Ancient Roman period, the senate usually held public debate in discussing political issues and government policies known as 'forum' (Pass, 2009). Some universities, colleges and high schools in European countries still name their debating team as 'forensics team' for any debating occasion or competition. Indeed, forensic science is the skill of carrying out scientific approaches to solve cases or investigation while basic science is the combination in knowledge and other definite methods such as experiment and observation. These cases or investigations are not limited to criminalistics only but are also extended to other types of investigation. In this manner, figh forensics is termed to refer to a practical knowledge derived from the revealed rulings gained from detailed scripts concerning the actions of applying scientific methodology in legal purposes or investigation for the intended application in the Islamic court (Jaishankar, et al., 2010; M. Crim, et al., 2001).

As early as 1910-1800 BCE, in the story of Prophet Yusuf related by the Quran, a few events that occurred contribute significance to the concept of figh forensics. The first of such event was found in the verses that elaborate on the tragedy of murder attempt from his siblings; his siblings then threw him into a well. Secondly, in the accusation of sexual assault made by the wife of the Egyptian governor when the evidence from his shirt then spoke for the truth. Thirdly, in the miracle of Yusuf's shirt brought by his siblings to Prophet Ya'qub in which Prophet Ya'qub could identify the smell of Yusuf on the shirt given even when he was blind (al-Qurtubi, 1964). Furthermore, the 400s CE is believed to be the beginning of forensic pathology when the ancient Egyptians began to perform autopsies on cadaver and presented the evidence to court (Inman, 2001). In the prophetic period of Prophet Muhammad, many events and cases related to the field of forensics appeared to be highlighted such as in the hadith related to paternity and li'ān. In fact, in the Battle of Badr, it can be concluded that to investigate on the real killer of Abu Jahal, Prophet Muhammad had used the Exchange Principle (later found by Locard) (Ibn Rajab, 1996).

The father of surgery and pathology, Abu Qasim al-Zahrawi from Zahra capital of Andalusia, made the job of forensic pathologists nowadays easier by his famous manuscript of al-Tasrif li man 'ajiza 'an ta'lif. It provides enormous contribution and pioneered the forensic pathology field with illustrations, works, approaches and devices. Some of the instrument and devices still in use today have been adopted from the book (al-Tikriti, 2005). Later, between 1204-1273 CE, al-Qurtubi who was also from Andalusia made mention in his exegesis of Surah al-Baqarah verse 273 which suggested the theory to identify deceased or mingled deceased bodies (in war or battle) from their clothing or external peculiarities such as circumcision. After the period of the four earlier caliphates ended some dressing code had been applied in Muslim territory for ahl-Dhimmah to distinguish them with Muslims from the appearance. During that time ahlDhimmah had to wear specific dress code which was known as ziyy al-Kuffär such as coloured girdle (zunnār), distinctive clothing (ghiyār) and cross (al-Haythami, 1983; al-Qurtubi, 1964; al-Tikriti, 2005; Levy-Rubin, 2011). If an unidentified body of a dead person was found the apparel worn by the person had been used to assist in the recognition process of the dead body (al-Nu'mānī, 1998).

In an in-depth discussion within the concept of justice and philosophy of evidence in Islam, Ibn Qayyim, al-Qarrafi and Ibn Farhun later made mention in their manuscripts on the elaboration of each of the cases mentioned in the form of historical analysis. Their manuscripts also emphasised to include this kind of evidence as a part of al-Bayyinah definition, thus expanding the al-Bayyinah definition to a wider scope. Some of the manuscripts extensively tried to elaborate more 
on sophisticated scientific approaches albeit limited to the constraint of technology at that time. The most important part is they tried to at least relate the forensic evidence with the realisation of maqasid al-shariah especially in the'Uqubat field (Ibn al-Qayyim, n.d.; Ibn Farhun, 1986; Ibn Qayyim, 1991). Al-Furūq by Shihāb al-Din al-Qarrāfi (n.d.) added more values to the history of forensic evidence in Islam by suggesting few maxims in using evidence as mean of proof. All in all, despite having advanced development in forensics technology, the origin of the concept of adapting scientific evidence and to integrate it with law is proven to be led by the Muslim community as the period of the Renaissance is believed to have started late in the $16^{\text {th }}$ century. Table 1 gives the timeline of important events in forensics history:

Table 1. Timeline of Important Forensics Events from Islamic Perspective

\begin{tabular}{|c|c|}
\hline Year & Important Events \\
\hline 1910-1800 BCE & $\begin{array}{l}\text { In Prophet Yusuf's period, the story of his murder, the accusation of immoral assault on the wife of Egypt's } \\
\text { governor, and individuality of his shirts, lead to more discussions in the topic of al-Qarinah in Islamic law }\end{array}$ \\
\hline 400s CE & $\begin{array}{l}\text { Ancient Egyptians are believed to perform exhumation on corpses and purposely carried out autopsies on } \\
\text { dead bodies and presented the evidence to the court for judgement }\end{array}$ \\
\hline 500-700 CE & $\begin{array}{l}\text { Prophet Muhammad and his companions agreed in some 'classical' principles of forensic science such as in } \\
\text { the use of al-Qāif in paternity test and in tracing culprits }\end{array}$ \\
\hline $624 \mathrm{CE}$ & $\begin{array}{l}\text { In the Battle of Badr, Prophet Muhammad used to investigate on the swords of two soldiers to determine the } \\
\text { killer of Abu Jahal } \\
\text { In the same battle, Abu Ubaydah al-Jarrah applied the method of estimating the strength of Quraysh troops } \\
\text { from footprints and dung of animals and human at enemy's camp site }\end{array}$ \\
\hline 700s CE & Fingerprint was used by the Chinese to develop identification of written material and clay carvings \\
\hline 936-1013 CE & $\begin{array}{l}\text { Abu Qasim Al-Zahrawi was a famous pioneer in introducing approaches and devices for surgery through his } \\
\text { al-Tasrif li man 'ajiza 'an al-Ta'lif thus, enhancing innovation in forensic pathology }\end{array}$ \\
\hline $1000 \mathrm{CE}$ & Quintilian who was a Roman attorney interpreted evidence from the prints of bloody palm to seize a murderer \\
\hline 1149 CE & $\begin{array}{l}\text { In Europe, King Richard for the first time suggested the idea of the coroner to carry out inquiry on certain } \\
\text { condition of death }\end{array}$ \\
\hline 1204-1273 CE & $\begin{array}{l}\text { Al-Qurtubi, in his exegesis of al-Qur'an, suggested the idea of distinguishing mingled deceased from external } \\
\text { peculiars such as girdle, types of apparel and circumcision which is renowned as part of identification } \\
\text { process in forensic science }\end{array}$ \\
\hline 1285 CE & $\begin{array}{l}\text { Al-Furuq by Shihāb al-Din al-Qarrāfi displays the importance of adapting maxims and specific principles such } \\
\text { as principle of individuality in investigation, exchange principle, and crime scene investigation towards } \\
\text { evidence including forensics related evidence and al-Qarinah }\end{array}$ \\
\hline 1292-1350 CE & $\begin{array}{l}\text { Ibn Qayyim wrote the book Turuq al-Hukmiyyah elaborating on the importance of forensic evidence to puzzle } \\
\text { out crimes and cases }\end{array}$ \\
\hline $1250-1343$ CE & $\begin{array}{l}\text { Tabyin al-Haqaiq writen by Fakhr al-Din al-Zayla'ie proposed the concept of identification of dead body from } \\
\text { apparel and cloth and peculiar evidence of deceased }\end{array}$ \\
\hline 1320-1397 CE & $\begin{array}{l}\text { Ibn Farhun wrote the book of Tabsirat al-Hukkam fi Usul al-'Aqdiyah wa Manāhij al-Ahkām which contains } \\
\text { examples of integrating forensic evidence and Islamic law }\end{array}$ \\
\hline $1557 \mathrm{CE}$ & $\begin{array}{l}\text { Muhammad bin Ahmad al-Sharbini known as al-Khatib al-Sharbini suggested the exhumation and autopsy of } \\
\text { the deceased in certain cases such as to save life of child in womb and to get back one's lavish property }\end{array}$ \\
\hline $1598 \mathrm{CE}$ & $\begin{array}{l}\text { Forensic medicine introduced by Fidelus and high-powered miscroscope constructed by Anton Van } \\
\text { Leeuwenhoek }\end{array}$ \\
\hline $1859 \mathrm{CE}$ & The science of spectroscopy was developed by Robert Bunsen and Gustav Kirchhoff \\
\hline $1864 \mathrm{CE}$ & Crime scene photography was introduced to the world \\
\hline 1879 CE & $\begin{array}{l}\text { World famous Alphonse Bertillon developed a system to establish the identity of people using particular body } \\
\text { measurements }\end{array}$ \\
\hline $1896 \mathrm{CE}$ & First classification system for fingerprint identification was developed by Edward Henry \\
\hline $1904 \mathrm{CE}$ & Edmond Locard introduced the Locard's Principle \\
\hline $1959 \mathrm{CE}$ & James Watson and Francis Crick discovered the deoxyribonucleic acid (DNA) double helix \\
\hline 1977 CE & $\begin{array}{l}\text { Automated Fingerprint Identification System (AFIS) developed by Federal Bureau of Investigation (FBI), fully } \\
\text { automated in } 1996\end{array}$ \\
\hline $1984 \mathrm{CE}$ & DNA tests were applied to a criminal case and developed by Jeffrey \\
\hline
\end{tabular}

\subsection{Law of Individuality and Locard's Principle}

These two basic principles make up the pillars of forensic science. In 1963, Paul Leland Kirk has found and made 
mention of the Law of Individuality which then constituted the pillars of forensic science (Claude Roux, 2009; Kirk, 1963). Kirk claimed that the prior aim of forensics is to focus on two items which are supposed to be sourced from a single originator and to come as closely as the existing science allows. He assumed that every single thing and object in the universe is unique (Kirk, 1963). This basis determines the identification of forensic evidence in forensics analysis. Apart from that, Kwan (1977) agreed and developed some statistical methodological basis for the identification of evidence which was later known as 'Bayesian approach' or 'Bayes theorem' (Urbach, 1989). This principle then has been used widely in many forensic researches, reports, journal articles and forensics analysis and development of forensic instruments and mechanisms. It should be noted that some of those who used this principle in their report include Ewen (2011), Bradford T. Ulery (2011), Page, et al., (2011) and Giannelli (2011). In the book of Forensic Science in Criminal Investigation and Trials, Sharma (1989) elaborated more on this principle which he quoted as:

'Every object, natural or man-made, has an individuality, which is not duplicated in any other object. It is unique. Neither the nature has duplicated itself nor man can'

(Sharma, 1989: 14)

At the first glimpse this principle looks like opposite in nature to the usual belief and observation although logically as a human we have never met or seen anyone exactly similar to ourselves in our lifetime except for twins. Michael Saks and Jay Koehler (2008) explained that it is very difficult to conclude on human characteristic to be recognizably different in nature in each particular person without checking every individual. Even though particles of sand or grains of common salt, twins or seed of plants may resemble others, but the individuality is still there. It is because of every single small fragment of the materials, the composition of crystals, specific inclusion and exclusion of unrelated substance or others are different (Sharma, 1989; Umi Kalthom \& Yacob, 2003). In early 1900s, people increasingly began to identify physical characteristic such as fingerprints, blood and bones. These in turn could be used to help establish the identity of a person. Bertillion's system of anthropometry for classifying nose types, for example, was designed on this basis (Encyclopedia of Science And Technology, 2007; Rhodes, 1956). However, this Bertillonage system suffered from a number of problems which are operational in nature such as slow, expensive, far from error free and non-availability of databases. Additionally there were several fundamental defects. Nevertheless it spurred the development of advanced technology in this forensic field for years and decades after (Bernard Roberston, 1995: 4).

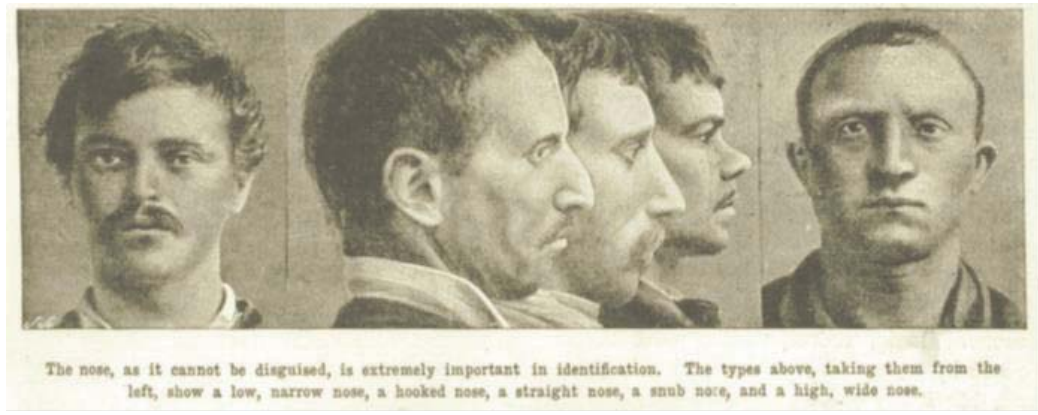

Figure 1. Illustration from The Speaking Portrait, an article from Pearson's Magazine, 1901 on Bertillon's System of Anthropometry for Classifying Nose Types (Farebrother \& Champkin, 2014)

Besides, distinctive quality of human has been verified and proven unique by this principle (Gary Edmond, 2013). The most definitive study has been carried out on fingerprints for an example. Millions of prints have been identified but no two fingers give the similarity on each other even from two fingers of the same individual (Alaa Ahmed Abbood, Ghazali Sulong \& Peters, 2014; Matthew B. Thompson, 2013; Sharma, 1989; Urbach, 1989). Series of experiments conducted to describe on the effect of superimposition techniques for fingerprints prove that with the best superimposed techniques, even from the same finger, the similarities could not be produced due to imperfect inking, unbalanced pressure, the texture of surface of paper and several other aspects (Bernard Roberston, 1995; Bradford T. Ulery, 2011; Sharma, 1989). With the evolution of science and technology on the forensic field and with new equipment and tools developed based on this principle including the systematic database for classification based on the individuality such as AFIS database of 1977, it is proven that the principle of individuality is still relevant for the time being (Bharadi, 2010). Consequently, in 
criminalistics areas of study, criminal, modus operandi, scene of crime, weapon of offence, sign, clues and everything involved in a crime are unique and has their own individuality. Recent studies show that even lip prints of human have their own individual characteristics (Kavitha, et al., 2009; Reddy, 2011; Saraswathi, et al., 2009; Verghese, et al., 2010).

Locard's Principle which is also known as Principle of Exchange or Locard's Exchange Principle is the most famous principle in forensics science history. It was developed by Edmond Locard who once came into conclusion in his book that 'every contact leaves trace' (Locard, 1920: 8). This principle accords that when a criminal and/or his tool of crime connects through physical touch with the victim or any other thing from the surrounding it leaves traces that can be analysed (R. E. Gaensslen, 1986). Similarly, this principle can also be applied if the criminal picks up traces from the same scene. The second part of this principle indicates that duration, intensity and nature of the materials in contact determine the extent of the transfer (Anthony J, 2008: 22). This principle indicates that skin and blood under a deceased's fingernails might be found and infer that they come from the criminal (Bernard Roberston, 1995; Saferstein \& Hall, 2001). Furthermore, in order to arrest a suspect on the basis of evidence, the former might come from the deceased such as clothing or fibres and yet traces of particular soil and plant types which correspond with those at the scene might also be discovered (Bernard Roberston, 1995: 3). The combination of these two principles together is of enormous potential value to the forensic scientist (Bernard Roberston, 1995: 4). As for the Principle of Exchange, Sharma (1989: 15) says that this principle is:

'Whenever two entities come in contact, there is an exchange of traces mutually' (Sharma 1989: 15)

Let us take a historical analysis on some cases that are related to the application of these principles in earlier Islamic history as pointed out before. First and foremost is the case study of Prophet Yusuf in the holy Quran in verse 94 Chapter 11. In this story the caravan of relatives and Prophet Yusuf's father departed Egypt heading towards their father's home in Palestine. Their father (Prophet Ya'qub) said to the relatives who were with him:

I feel the breath of Yusuf. If you do not think that I am in my dotage (surely you will believe me).

(Al-Quran 12: 94)

Sayyid Qutb says in his tafsir, that Yusuf's father has been able to detect the sign of Yusuf before the relatives of Yusuf gave the shirt of Yusuf to him (Prophet Ya'qub). In this situation, after the relatives gave the shirt to him, he then recognized the scent form the shirt to be individually from Yusuf, his son (Sayyid Qutb, 1993). In relation to this story, the principle of individuality as told by Gary Edmond (2013), the uniqueness and distinctive quality of a human has been verified by the unique smell and scent from the shirt of Prophet Yusuf. In this case, Prophet Ya'qub seemed to affirm that he could identify the smell because he is the father and he knows his son better since he had brought up Yusuf. Furthermore Yusuf was also his most beloved kid (Sayyid Qutb, 1993). As in forensic science the human scent or body odour has been established to be unique to the individual since a very long time ago (Lenochova \& Havlicek, 2008; Penn et al., 2007; Revathi Rajan, 2013). The whole idea of the principle of individuality of human scent is that human odour is a unique physical characteristic of every individual and that this odour is left at every place, thing, material or track which the subject has come in to chain with (Paola A. Prada, et al., 2008; Schoon \& De Bruin, 1994).

In addition, in the highlighted story of the tragedy of the same prophet (Yusuf), when he was thrown into a well his siblings brought back to their father Yusuf's shirt that was stained with blood. It is as mentioned in Surah Yusuf verse 18 which is interpreted by exegesis scholars that the siblings of Prophet Yusuf used the blood of a lamb instead of the blood of Prophet Yusuf as an evidence for the latter's death (al-Suyuti, 1993; Sayyid Qutb, 1993; Sha'rawi, 1997). As a construct of the crime their father has recognized that the blood was not from a human based on his earlier experience as a shepherd. In fact, the recognition of types of blood can also be classified under the Principle of Individuality (Joysey, 1959; Karl Lansteiner, 1934, p. 1041).

In another instance these two principles are also highlighted in the story of the death of Abu Jahal in the Battle of Badr (Ibn Rajab, 1996). There were two young Ansari boys namely Mu'adh bin 'Amru bin al-Jamuh and Mu'adh bin 'Afra. Both of them attacked Abu Jahal with their swords and struck him to death. They returned to Prophet Muhammad (p.b.u.h.) to inform him of that particular incident (Ibn Rajab, 1996). Prophet Muhammad (p.b.u.h.) investigated on the swords and confirmed that they both have striked Abu Jahal but the salab (spoils) of war would be given to Mu'adh bin 'Amru bin al-Jamuh. This is due to the finding by the Prophet that the sword of Ibn al-Jamuh had been driven deep in the body of the killed man, Abu Jahal (Ibn Rajab, 1996; Khan, 1997). Law of exchange states that when a man and/or his tool of crime connects through physical touch with the victim or any other thing from the surrounding it leaves traces that can be analysed (Claude Roux, 2009; Peschel, et al., 2011; R. E. Gaensslen, 1986). This principle can be applied to the 
investigation by Prophet Muhammad (p.b.u.h.) on both swords as they had not yet cleaned the swords at that time (Ibn Rajab, 1996).

The application of these two principles are clearly demonstrated and reported in the Islamic history and it cannot be doubted that they are part of the most important principle in forensic evidence as they are keys to other principles. Hence, as a conclusion, these two principles of individuality and the principle of exchange are applicable in Islamic law, proven by historical analysis of some cases that have used them as a basic principle. Therefore, the integration of these two principles with Islam can be drafted as in Figure 2.

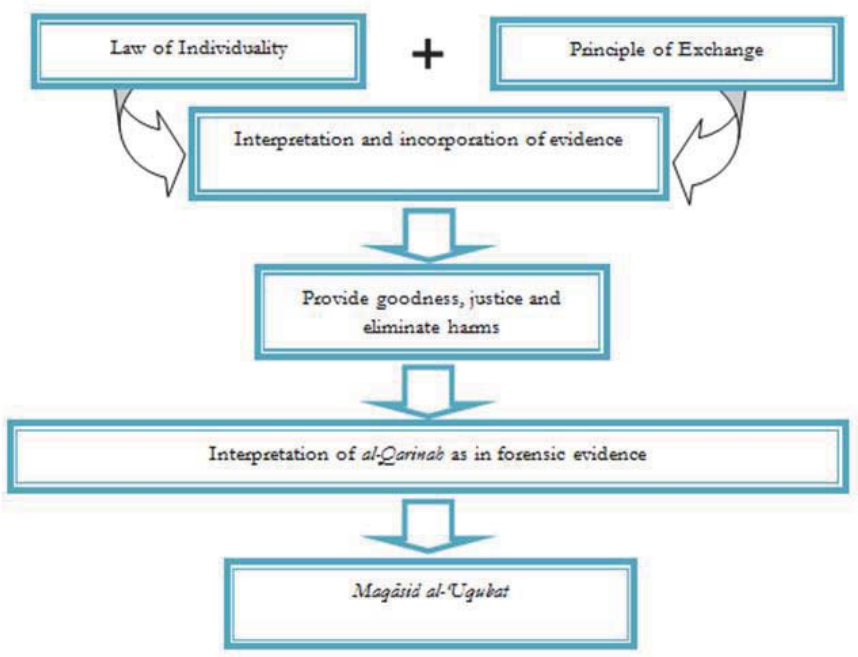

Figure 2. Law of Individuality and Principle of Exchange in Relations with Maqāsid al-Shariah Reconstructed from Bernard Roberston (1995) and al-Shātibī (1997)

\subsection{Forensic Evidence, al-Qarinah, and al-Bayyinah}

Significantly, this topic offers an evergreen discussion in relation to Islamic law and jurisprudence within the interpretation of various scripts of al-Qur'an and al-Sunnah. By the time of Caliph Harun al-Rashid, Qadi Abu Yusuf suggested the rethinking of the admissibility and the presence of evidence in judging any case related to the complaint made by a claimant (Hallaq, 2004). Moreover, three different views in the definition of al-Bayyinah give a never ending debate in order to include al-Qarinah or forensic evidence under the classification of al-Bayyinah. The first opinion proposed by the Shafiis (al-Sharbini, 1994), Hanafis (al-Sarkhasi, 1993) and Hanbali schools (Ibn Qudamah, 1968) which concluded alBayyinah as only the testimony of witnesses (al-Shahadah). Meanwhile Ibn Hazm later added 'ilm Qadhi (knowledge of judge) into the definition and considered it as the strongest type of al-Bayyinah (Ibn Hazm, n.d.). The third view is represented by the jurists of the seventh century of Hijrah, namely; Ibn Taymiyyah (1995), Ibn al-Qayyim (n.d.), Ibn Farhun (1986), Abu al- Hasan al-Tarablusi (n.d.), and Ibn al-Ghars (n.d.) in which, after a long elaboration relating to the maqasid, they came to the conclusion that al-Bayyinah is a name for anything that can demonstrate the truth which duly extends the meaning beyond the testimony of witnesses and ilm Qãdi. This study believes that forensic evidence could be categorized as part of al-Bayyinah by referring to the third view based on the strong dalil given and also because it contributes better to maqasid 'Uqubat as argued by al-Zuhayli, (2006, p. 586). With that, forensic evidence is included under the classification of al-Bayyinah and could also be referred to as al-Qarinah.

Truly, al-Bayyinah is a crucial part of the realization of maqāsid al-Shari'ah. Maqāsid al-Shari'ah is the implementation of Islamic law in order to help ensure that justice is upheld and injustice is eliminated (Ibn 'Ashur, 2001). Maqāsid is also a systematic approach and process in preserving the human institutions that cannot be achieved without any emphasis on the human institutional law. The focus of Islamic law (criminal law) namely al-Hudud, al-Qisas, al-Diyat and al-Ta'zir are to educate the wrongdoer, to give satisfaction towards the victim and the family and provide instruction (model) to the people so as not to do the same misdeeds, crimes or wrongdoings (al-Sulami, 1991; Ibn 'Ashur, 2001; Ibn 
Qayyim, 1991). These prior elements of Islamic law are contributing to preserve al-Darūriyyāt al-Khamsah in maqāsid alShari'ah (al-Shāțibī, 1997). Consequently, al-Bayyinah is one of the means of proof to help the judge come into a correct decision (M. M. al-Zuhayli, 1982). It plays important role in the preservation of al-Darūriyyāt al-Khamsah in every related element such as in the preservation of al-Mal (property), human rights and al-Nasl (lineage) (Mulhim, 2005). Hence, the role of forensic evidence as al-Bayyinah alternatively provides a new way out to the issues of inconsistency and fallacy in the implementation of Islamic law.

\subsection{Relationship between Locard's Principle and Law of Individuality with Maqasid 'Uqubat}

Although these two basic principles have never been mentioned clearly in any classical manuscripts, these principles give significantly big impacts towards the realisation of maqasid of Islamic law. Etymologically, maqāsid is a plural form of the word maqsud or maqsad which means the objective, aim and also intention (Ibn Manzur, 1994). He also defined the word derived from al-qasdu which also refers to al-'adlu (justice). Discussed in detailed and specific form during 500 A.H. by Imam al-Haramayn al-Juwayni, this field developed until end of $700 \mathrm{~A} . \mathrm{H}$. According to Imam al-Shatibi the definition of maqasid is different due to their understandings of scripts. In general, Maqasid Shari'ah refers to the objectives and aims of divine law for the human benefits whether it is for the personal or public context.

As mukammilat to al-Daruriyyat, the two principles of forensic science in this study demonstrate on how alBayyinah plays a vital role in accomplishing Maqasid 'Uqubat (Mulhim, 2005). The role of al-Bayyinah as a means of alternative proof addresses the deficiency of finding the right certified witnesses in accordance to syara'. Forensic science, if it cannot technically solve some cases, could at least act as a deterrance and reminder to criminals that evidence can speak for itself. Forensic science and legal practice cannot be established without sound basis and foundation. As proven from history and the development of technology these principles of forensics could also be the foundation in realisng Maqasid 'Uqubat. Figure 3 shows the connection between forensics principles and Maqasid 'Uqubat.

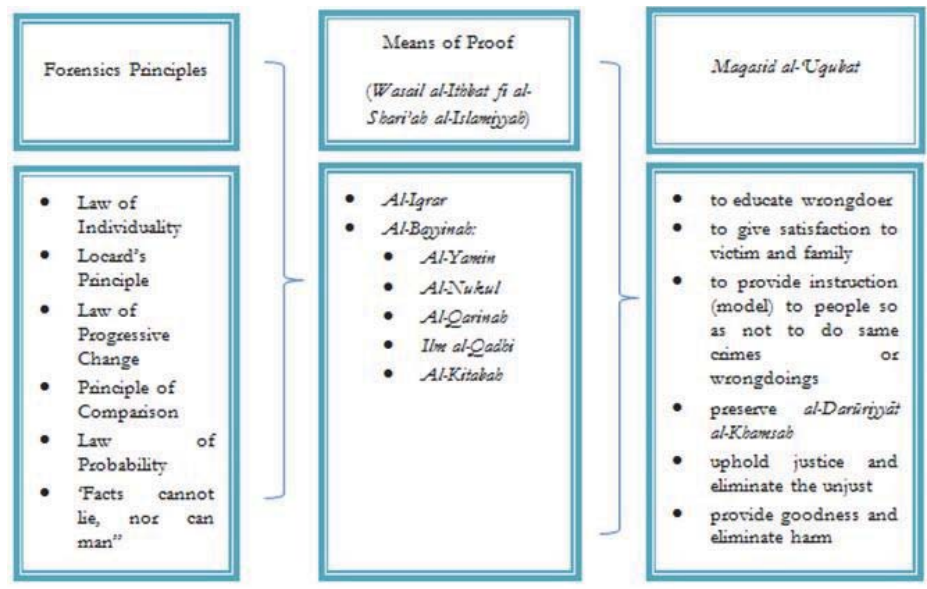

Figure 3. The Role of Forensics Principles in Realising Maqasid al-'Uqubat adapted from al-Shāțibī (1997), Sharma (1989), Kamdar and Pandey (2011), al-Zuhayli (1982) and Ibn al-Qayyim (n.d.)

\section{Implications of the Research}

1. This study found that forensic science had been used widely in Islamic history and has its own figh.

2. The literature review of this study can be an eye opener to further researches in the field of the philosophy of forensic science in Islam

3. The results of the study indicated a positive relation between forensic science, al-Qarinah and Maqasid al'Uqubat in order to rejuvenate Islamic Criminal Law. 


\section{Conclusion}

The integration between forensic science and Islamic law rejuvenates and refreshes the way the world sees and thinks about Islamic law. It is a crucial need to integrate between science and Islamic law as the Islamic history has never separated them. This paper suggests that more extensive literature and research be made to investigate other native and non-native principles of forensic science. It would be a huge loss to Islamic law if this field cannot benefit the Muslim community at least as deterrence and a sign of warning to aspiring criminals or wrongdoers as the forensic evidence can speak for itself. Moreover, the fallacy in understanding this integration and the concept of figh forensics can lead to a big loss and waste to Muslims as it is one of the best tools to keep and preserve justice in human life thus providing and sustaining benefits and eliminates harm.

\section{References}

\section{Al-Quran}

Ahmad Syukran Baharuddin, Hasna Bidin, Wan Ismail Wan Dagang, Aminuddin Ruskam, \& Abdul Rahim Yacob. (2015). Figh Forensics: Integration between Sciences and Islamic Law for Autopsies and Identification of Deceased. Sains Humanika, 4(2).

Ahmad Syukran Baharuddin, Aminuddin Ruskam, \& Abdul Rahim Yacob. (2015). The Role of Forensic Biology in Realising Maqāsid alShariah (The Objectives of Islamic Law). Sains Humanika, 4(1).

al-Haythami, I. H. M. A. (1983). Tuhfat al-muhtaj bi sharh al-minhaj. Beyrut: Dar Ihya al-Turath al-'Arabi.

al-Nu'mānī, A. H.. S. a.-D. U. (1998). al-Lubāb fi 'Ulūm al-Kitāb (A. A. A. Mawjūd Ed.). Beyrūt: Dār al-Kutub al-'Ilmiyyah.

al-Qarrāfi, A. b. I. b. A. a.-R. S. a.-D. (n.d.). al-Furūq. Beirut: Ālam al-Kutub.

al-Qurtubi, A. A. A. b. M. S. (1964). Tafsir al-Qurtubi. Cairo: Dar al-Kutub al-Masriyyah.

al-Sarkhasi, S. a.-D. (1993). al-Mabsut. Beirut: Dar al-Ma'rifah.

al-Sharbini, S. a.-D. a.-K. (1994). Mughni al-Muhtaj ila Ma'rifat Ma'ani alfaz al-Minhaj. Beirut, Lubnan: Dar al-Kutub al-'Ilmiyyah.

al-Shāțibī, I. B. M. (1997). al-Muwāfaqāt (A. U. M. B. H. A. Salmān Ed.). Mesir: Dār Ibn 'affān.

al-Sulami, I. a.-D. A. A. (1991). Qawa'id al-Ahkam fi Masalih al-Anam. Cairo: Maktabah al-Kulliyat al-Azhariyyah.

al-Suyuti, J. A. R. (1993). Tafsir Al-Jalalain. Beirut: Dar al-Fikr.

al-Tarablusi, A. a.-H. a. a.-D. (n.d.). Mu'in al-Hukkam fi ma Yataraddadu bayna al-Khasmayn min al-Ahkam: Dar al-Fikr.

al-Tikriti, N. (2005). Kalam in the Service of State: Apostasy and the Defining of Ottoman Islamic Identity. Legitimizing the Order: The Ottoman Rhetoric of State Power, 131-150.

al-Zarkashī, A. A. B. a.-D. M. (1994). al-Baḥr al-Muhịt. Beyrūt: Dār al-Kutub al-Ilmiyyah.

al-Zayla'i, U. b. A. F. a.-D. (1992). Tabyin al-Haqa'iq. Cairo: maktabah al-Kubra al-Amiriyyah.

al-Zuhayli, M. M. (1982). Wasail al-Ithbat fi al-Shari'ah al-Islamiyyah fi al-Muamalat al-Madaniyyah wa al-Ahwal al-Shakhsiyyah. Damascus: Maktabah Dar al-Bayan.

al-Zuhayli, M. M. (2006). Al-Qawā'id al-Fiqhiyyah wa țațbīqātuhā fĩ al-madhāhib al-Arba'ah. Damascus: Dār al-Fikr.

al-Zuhayli, W. I. M. (n.d.). Al-Figh al-Islami wa Adillatuh. Damascus: Dar al-Fikr.

Alaa Ahmed Abbood, Ghazali Sulong, \& Peters, S. U. (2014). A Review of Fingerprint Image Pre-processing. Jurnal Teknologi, 69(Special Issue), 79-84.

Anthony J, B. (2008). Forensic Science Fundamentals and Investigations. United States of America: South Western Cengage Learning.

Bernard Roberston, G. A. V. (1995). Interpreting Evidence: Evaluating Forensic Science in the Courtroom. United Kingdom: John Wiley \& Son Ltd.

Bharadi, H. B. K. a. V. A. (2010). Fingerprint Core Point Detection Algorithm using Orientation Field Based Multiple Features. International Journal of Computer Applications, 5(18). doi: 10.5120/314-482

Bradford T. Ulery, R. A. H., JoAnn Buscaglia, and Maria Antonia Roberts. (2011). Accuracy and reliability of forensic latent fingerprint decisions. Proceedings of the National Academy of Sciences of the United States of America(Early Edition). doi: 10.1073/pnas. 1018707108

Claude Roux, F. C. a. O. R. (2009). Strengthening Forensic Science in the United States: A Path Forward. United States of America.

Encyclopedia of Science And Technology. (2007). Ohio, United States of America: R. R. Donneley.

Ewen, T. (2011). The Role and Impact of Forensic Evidence in the Criminal Justice System, Final Report (U. S. D. o. Justice, Trans.). Virginia: National Institute of Justice.

Farebrother, R., \& Champkin, J. (2014). Alphonse Bertillon and the measure of man: More expert than Sherlock Holmes. Significance, 11(2), 36-39. doi: 10.1111/j.1740-9713.2014.00739.x

Gary Edmond, M. B. T., Jason M. Tangen. (2013). A guide to interpreting forensic testimony: Scientific approaches. Law, Probability and Risk, 1-25.

Giannelli, P. C. (2011). Daubert and forensic science: The pitfalls of law enforcement control of scientific research. U. III. L. Rev., 53.

Hallaq, W. B. (2004). The Origins and Evolution of Islamic Law: Cambridge University Press.

Ibn 'Ashur, M. T. B. M. (2001). Maqāsid al-Shari'ah al-Islāmiyyah. Jordan: Dār al-Nafäis.

Ibn al-Qayyim, S. a.-D. M. (n.d.). Al-Turuq al-Hukmiyyah. Beirut: Dar al-Kutub al-'Ilmiyyah.

Ibn Farhun, I. B. A. B. M. B. (1986). Tabsirah al-Hukkam fi Usul al-Aqdiyah wa Manahij al-Ahkam. Cairo: Maktabah al-Azhari. 
Ibn Hazm, A. M. A. (n.d.). Al-Muhalla bi al-Athar. Beirut: Dar al-Fikr.

Ibn Manzur, a.-A. (1994). Lisan al-'Arab. Beirut: Dar al-Sadr.

Ibn Nujaym, Z. a.-D. (n.d.). Bahr al-Raiq fi Sharh Kanz al-Daqaiq: Dar al-Kitab al-Islamiyyah.

Ibn Qayyim, S. a.-D. M. (1991). I'lam al-Muwaqi'in 'an Rabb al-'Alamin. Beirut: Dar al-Kutub al-'Ilmiyyah.

Ibn Qudamah, A. M. (1968). al-Mughni. Cairo, Egypt: Maktabah al-Qahirah.

Ibn Rajab, a.-H. (1996). Fath al-Bari Sharh Sahih al-Bukhari. Cairo: Maktab al-Tahqiq Dar al-Haramayn.

Ibn Taymiyyah, T. a.-D. A. (1995). Majmu' al-Fatawa. Medina: Majma al-Malik Fahad litiba'ah al-Mushaf al-Sharif.

Inman, K. (2001). Principles and Practice of Criminalistics, The Profession of Forensic Science. Florida, U.S.A: CRC Press LLC.

Jaishankar, S., Jaishankar, N., \& Shanmugam, S. (2010). Lip prints in personal identification. J Indian Acad Dent Specialists, 1(4), 2326.

Joysey, V. C. (1959). The relation between animal and human blood groups. British medical bulletin, 15(2), 158-164.

Kamdar, S. R., \& Pandey, A. (2011). The Scope of Artificial Intelligence in Forensic Science. Forensic Audit, 46.

Karl Lansteiner, M. D. (1934). Forensic Application of Serology Individuaity Test. The Journal of American Medical Association, 10411044.

Kavitha, B., Einstein, A., Sivapathasundharam, B., \& Saraswathi, T. (2009). Limitations in forensic odontology. Journal of forensic dental sciences, $1(1), 8$

Khan, D. M. M. (1997). The Translation of the Meanings of Sahih al-Bukhari. Riyadh, Kingdom of Saudi Arabia: Darussalam Publishers and Distributors.

Kirk, P. L. (1963). The Ontogeny of Criminalistics. The Journal of Criminal Law, Criminology, and Police Science, 54(2), 3.

Koehler, M. J. S. J. J. (2008). The Individualization Fallacy in Forensic Science Evidence. Vanderbilt Law Review, 200-219.

Kwan, Q. Y. (1977). Inference of Identity of Source: University of California, Berkeley.

Lenochova, P., \& Havlicek, J. (2008). Human body odour individuality Chemical Signals in Vertebrates 11 (pp. 189-198): Springer.

Levy-Rubin, M. (2011). Non-Muslims in the early Islamic empire: from surrender to coexistence: Cambridge University Press.

Locard, E. (1920). L'enquête criminelle et les méthodes scientifiques: E. Flammarion.

M.Crim, Keith Inman, \& Rudin, N. (2001). Principles and Practice of Criminalistics: The profession of Forensic Science. United States of America: CRC Press.

Matthew B. Thompson, J. M. T. a. D. J. M. (2013). Expertise in Fingerprint Identification. Journal of Forensic Sciences, 58(6), 15191530. doi: $10.1111 / 1556-4029.12203$

Mulhim, B. A. B. (2005). Maqasid Al-Shari'ah Al-Islamiyyah fi Al-Shahadat. Amman: Dar An-Nafais.

Page, M., Taylor, J., \& Blenkin, M. (2011). Uniqueness in the forensic identification sciences-Fact or fiction? Forensic science international, 206(1), 12-18.

Paola A. Prada, B.S., K., \& Furton, G. (2008). Human Scent Detection: A review of Its Development and Forensic Applications. Revista de Ciencias Forenses, 1 (2), 81-87.

Pass, A. E.-S. A. D. (2009). Forensic! United States of America: Hamilton Printing Company.

Penn, D. J., Oberzaucher, E., Grammer, K., Fischer, G., Soini, H. A., Wiesler, D., . . . Brereton, R. G. (2007). Individual and gender fingerprints in human body odour. Journal of the Royal society interface, 4(13), 331-340.

Peschel, O., Kunz, S., Rothschild, M., \& Mützel, E. (2011). Blood stain pattern analysis. Forensic science, medicine, and pathology, 7(3), 257-270.

R. E. Gaensslen, P. J. D., Henry C. Lee. (1986). Genetic Marker Systems Individualization of Blood and Body Fluids Forensic Science (pp. 209-240). Washington: American Chemical Society.

Reddy, L. (2011). Lip prints: An overview in forensic dentistry. J Adv Dent Res, 11, 16-20.

Revathi Rajan, N. F. N. H., Mohammed Nasimul Islam. (2013). Chemical Fingerprinting of Human Body Odour: An Overview of Prevoius Studies. Malaysian Journal of Forensic Sciences 4(1), 33-38.

Rhodes, H. T. F. (1956). Alphonse Bertillon, father of scientific detection: Abelard-Schuman.

Saferstein, R., \& Hall, P. (2001). An Introduction to Forensic Science. Criminalistics. Prentice Hall, Upper Saddle River, New Jersy, 108112.

Saraswathi, T., Mishra, G., \& Ranganathan, K. (2009). Study of lip prints. Journal of forensic dental sciences, 1(1), 28.

Sayyid Qutb, I. H. (1993). Tafsir fi Zilal Al-Qur'an. Beirut, Lubnan: Dar Syuruq.

Schoon, G. A., \& De Bruin, J. (1994). The ability of dogs to recognize and cross-match human odours. Forensic science international, $69(2), 111-118$

Sha'rawi, M. M. (1997). Tafsir As-Sha'rawi -Al-Khawatir. Cairo: Matabi' Akhbar Alyaum.

Sharma, B. R. (1989). Forensic Science in Criminal Investigation and Trials. India.

Umi Kalthom Ahmad, \& Yacob, A. R. (2003). Pengenalan Sains Forensik. Skudai: Penerbit Unvesiti Teknologi Malaysia.

Urbach, C. H. a. P. (1989). Scientific Reasoning: The Bayesian Approach. United States of America: Open Court Publishing Company.

Verghese, A. J., Somasekar, M., \& Umesh Babu, R. (2010). A study on lip print types among the people of Kerala. Journal of Indian Academy of Forensic Medicine, 32(1), 6-7. 